\title{
PASTORALNE PRZESLANIE KOMENTARZA ŚW. CEZAREGO Z ARLES DO APOKALIPSY ŚW. JANA
}

Objaśnienie Objawienia św. Jana autorstwa św. Cezarego z Arles jest dziełem mało znanym. O. Augustyn Jankowski OSB w wykazie patrystycznych komentarzy do Apokalipsy św. Jana, opracowanym w połowie XX w., nie umieścił dzieła biskupa Arles ${ }^{1}$. Uczyniono to natomiast w wydanym we Włoszech zbiorze wybranych komentarzy Ojców Kościoła i mistyków do Apokalipsy, ale nie przypisując jednoznacznie autorstwa Objaśnienia św. Cezaremu. Imię biskupa Arles umieszczono bowiem w nawiasie, pozostawiając - zgodnie z tezą Maurynów - Pseudo-Augustyna jako autora² ${ }^{2}$ Tymczasem już przed II wojną światową Germain Morin, na podstawie analizy porównawczej z innym dziełami Prymasa Galii, przyznał mu autorstwo komentarza ${ }^{3}$. Dzisiaj nikt nie kwestionuje tej opinii. Dzieło to jest uznawane jako ogromnie ważne dla historii egzegezy Apokalipsy św. Jana Apostoła, co zostanie omówione pokrótce w pierwszej części artykułu. Natomiast druga, zasadnicza część niniejszego opracowania, jest poświęcona omówieniu pastoralnego przesłania dzieła biskupa Arles.

1. Znaczenie dzieła biskupa Arles w historii egzegezy Apokalipsy św. Jana. Objaśnienie Objawienia św. Jana jest jednym z niewielu zachowanych do dzisiaj starożytnych komentarzy do Apokalipsy św. Jana ${ }^{4}$. Oprócz dzieła Cezarego posiadamy do dyspozycji jeszcze następujące starożytne i wczesnośredniowieczne komentarze o różnej objętości i o różnym znaczeniu: komentarz Wiktoryna z Patawium († ok. 304) ${ }^{5}$, odkryty w Archiwum

\footnotetext{
* Ks. dr hab. Paweł Wygralak, prof. UAM - profesor nadzwyczajny w Zakładzie Teologii Patrystycznej na Wydziale Teologicznym Uniwersytetu im. Adama Mickiewicza w Poznaniu; e-mail: pawelwyg@amu.edu.pl.

${ }^{1}$ Por. Apokalipsa świętego Jana, Wstęp, przekład, komentarz A. Jankowski, Poznań 1959, 18-20.

${ }^{2}$ Por. Apocalisse di Giovanni, con commento tratto dai Padri, Santi e Mistici della Chiesa, Montespertoli 1997.

${ }^{3}$ Por. G. Morin, Le commentaire homilétique de S. Cesaire sur l'Apocalypse, RBen 45 (1933) 43-61.

${ }^{4}$ Por. P. Wygralak, Święty Cezary z Arles jako egzegeta i teolog, w: Cezary z Arles, Pisma dogmatyczne i egzegetyczne, POK 29, Poznań 2004, 22-28.

${ }^{5}$ Por. Victorinus Poetovionensis, Commentarii in Apocalypsim Joannis, ed. M. Dulaey, SCh 423, Paris 1997.
} 
Watykańskim dopiero w 1916 r.; komentarz opracowany przez Prymazjusza z Hadrumetum (VI w.) ${ }^{6}$; łaciński komentarz żyjącego w VI w. biskupa Pax Iulia (Beja) ${ }^{7}$ - Apringiusza; komentarz Andrzeja († ok. 614), biskupa Cezarei Kapadockiej ${ }^{8}$; oraz późniejsze komentarze Bedy Wielebnego $(\uparrow 735)^{9}$, Ambrożego Autperta $(† 784)^{10}$ i Beatusa z Liebany $(\dagger \text { ok. 800 })^{11}$. Wskazane dzieła objaśniające ostatnią księgę Nowego Testamentu nie są oczywiście jedynymi jakie powstały w pierwszych wiekach chrześcijaństwa. Zgodnie z informacja Euzebiusza z Cezarei, poświadczoną przez św. Hieronima ${ }^{12}$, pełny komentarz do Apokalipsy opracował Meliton z Sardes. Jego dzieło pt. O diable i Apokalipsie św. Jana niestety należy uznać za zaginione, podobnie jak komentarze opracowane przez Hipolita $(\dagger 235)$ i Orygenesa $(\dagger 254)^{13}$. Poświadczeniem pracy Orygenesa może być świadectwo wczesnośredniowiecznego irlandzkiego autora, który zapewniał, iż korzystał z dwunastu homilii Aleksandryjczyka komentujących Apokalipsę ${ }^{14}$. Również inni autorzy podejmowali się komentowania jeśli nie całego tekstu Apokalipsy, to przynajmniej jej fragmentów ${ }^{15}$.

Nie sposób, omawiając starożytne komentarze do Apokalipsy, pominąć zaginione niestety dzieło Tykoniusza $\left(\dagger\right.$ ok. 390) ${ }^{16}$. Ten świecki człowiek, donatysta, opracował komentarz, który wywarł ogromny wpływ na późniejsze opracowania Apokalipsy św. Jana, m.in. wspomnianego już Prymazjusza, który starał się oczyścić komentarz Tykoniusza z wszystkiego, co można by uznać za heterodoksyjne, czy Cezarego z Arles, który z dziełem Tykoniusza

\footnotetext{
${ }^{6}$ Por. Primasius Hadrumetinus, Commentarius in Apocalypsin, ed. A.W. Adams, CCL 92, Turnholti 1985. Na temat komentarzy do Apokalipsy we wczesnym średniowieczu zob. The Apocalypse in the Middle Ages, ed. R.K. Emmerson - B. McGinn, New York 1993.

${ }^{7}$ Por. Apringius Pacensis, Tractatus in Apocalypsin, ed. R. Gryson, CCL 107, Turnhout 2003, 35-97. Zachowały się tylko fragmenty komentarza.

${ }^{8}$ Por. Andreas Caesariensis, Commentarii in Apocalypsin, PG 106, 215-458, 1387-1394.

${ }^{9}$ Por. Beda Venerabilis, Explanatio Apocalypsis, PL 93, 129-206.

${ }^{10}$ Por. Ambrosius Autpertus, Expositionis in Apocalypsin, ed. R. Weber, CCCM 27-27A, Turnhout 1975.

${ }^{11}$ Por. Beatus Liebanensis, Tractatus de Apocalipsin, ed. R. Gryson - M.-C. de Bièvre, CCL 107B-C, Turnhout 2012.

${ }^{12}$ Por. Eusebius Caesariensis, HE IV 26, 2; Hieronymus, De viris illustribus 61.

${ }^{13}$ Por. C. Diobounitis - A. Von Harnack, Der Scholien Kommentar des Origenes zur Apokalypse Johannis, TU 38, 3, Leipzig 1911.

${ }^{14}$ Por. J.F.T. Kelly, Early Medieval Evidence for Twelve Homilies by Origen on the Apocalypse, VigCh 39 (1985) 273-266; J. Naumowicz, Wstęp, w: Pierwsze tacińskie komentarze do Apokalipsy, Warszawa 2011, 26-27.

${ }^{15}$ Por. E.R. Pose, Introducción, w: Cesáro de Arlés, Comentario al Apocalipsis, Madrid 1994, $10-13$.

${ }^{16}$ Zachowały się pewne fragmenty dzieła Tykoniusza. Szerzej o tym: S. Adamiak, Eklezjologiczny charakter Komentarza do Apokalipsy donatysty Tykoniusza, BPTh 5 (2012) 152; R. Gryson, Fragments inedits du commentaire de Tyconius sur l'Apocalypse, RBen 107 (1997) 189-226; Lo Bue F. - G.G. Wilis, The Turin Fragments of Tyconius' Commentary on Revelation, Text and Studies. New Series 7, Cambridge 1963.
} 
spotkał się być może już w czasie swego pobytu w klasztorze w Lerynie oraz Beatusa z Liebany, Bedy Czcigodnego i Ambrożego Autperta ${ }^{17}$. Można bez żadnych wątpliwości powiedzieć, że cała łacińska tradycja egzegetyczna począwszy od końca IV w. była zależna od komentarza Tykoniusza. Na podstawie komentarzy tych autorów, a także zachowanych nielicznych fragmentów oryginału, udało się Rogerowi Grysonowi odtworzyć znaczną część dzieła Tykoniusza $^{18}$. Należy jeszcze nadmienić, że Tykoniusz był wspaniałym egzegetą. Jest bowiem autorem Liber regularum, jednego z najważniejszych dzieł W starożytności chrześcijańskiej na temat hermeneutyki biblijnej ${ }^{19}$. Komentarz Cezarego, i to jest jego istotne znaczenie dla poznania historii egzegezy, pozwala - jak to stwierdza hiszpański znawca starożytnych komentarzy do Apokalipsy Eugenio Romoro Pose - przeprowadzić w pewnym stopniu rekonstrukcję dzieła Tykoniusza ${ }^{20}$.

\section{Wartość pastoralna dzieła Cezarego z Arles. Objaśnienie Objawienia} $s ́$ w. Jana składa się z dziewiętnastu szkiców do homilii, w których autor podejmuje się dokonania egzegezy wybranych przez siebie fragmentów Apokalipsy. Wydaje się, że są to bardziej notatki, a może konspekt, który być może posłużył kaznodziei w przygotowaniu wypowiedzi na temat ostatniej księgi Nowego Testamentu. Przyglądając się strukturze szkiców oraz używanym zwrotom, można poddać w wątpliwość, czy homilie te zostały kiedykolwiek wygłoszone przez galijskiego duszpasterza. Pamiętając jednak pierwsze kazanie Cezarego z jego obszernego zbioru kazań, które skierował do kapłanów i biskupów, możemy przyjąć hipotezę, że i tymi szkicami chciał ich biskup wesprzeć zarówno na polu troski o zachowanie prawowierności, jak i na polu objaśniania trudnej do interpretacji ostatniej ksieggi Nowego Testamentu. Ponadto komentarze te stanowią kolejne świadectwo o biblijnej duchowości biskupa Arles.

W zaprezentowanej egzegezie Apokalipsy św. Jana, podobnie jak w komentarzach do innych fragmentów Pisma Świętego ${ }^{21}$, autor posługuje się metodą alegoryczną. G. Morin analizując tekst dzieła Cezarego zauważył, że końcowe fragmenty niektórych homilii (I, VI, VII, XVII, XVIII, XIX) stanowią podsumowanie zawierające jednak i takie treści, o których wcześniej nie było mowy ${ }^{22}$.

\footnotetext{
${ }^{17}$ Por. Adamiak, Eklezjologiczny charakter Komentarza do Apokalipsy, s. 152-153.

${ }^{18}$ Por. Tyconius, Expositio Apocalypseos, ed. R. Gryson, CCL 107A, Turnhout 2011.

${ }^{19}$ Por. Pose, Introducción, s. 13.

${ }^{20}$ Por. tamże, 16-17; G. Langärtner, Der Apokalypse-Kommentar des Caesarius von Arles, ThG 57 (1967) 211.

${ }^{21}$ Por. J. Correau, L'exégèse allégorique de saint Césaire d'Arles, BLE 78 (1977) 181-206. J. Dybczyńska, Egzegeza alegoryczna w kazaniach Cezarego z Arles jako narzędzie głoszenia stowa Bożego, w: Refleksja Ojców Kościoła nad słowem Bożym, red. B. Częsz, Poznań 2009 = TPatr 6 (2009) 121-142.

${ }^{22}$ Por. A. Żurek, Wstęp, w: Cezary z Arles, Homilie do Księgi Rodzaju, Objaśnienie Apokalipsy św. Jana, BOK 17, Kraków 2002, 18.
} 
Cezary we wprowadzeniu do swego komentarza wspomina o wcześniejszych komentarzach do Apokalipsy:

„Bracia najmilsi, sprawy, o których mówi Objawienie św. Jana, niektórzy starożytni ojcowie w ten sposób pojmują, że wykład albo cały, albo w przeważającej części, zdaje się dotyczyć dnia Sądu lub przyjścia Antychrysta”"23.

Wydaje się, że biskup Arles nie ma zamiaru stawiać na pierwszym miejscu eschatologicznych treści zawartych w Apokalipsie. Nie znaczy to jednak, że takie refleksje nie pojawiają się w jego komentarzu. Cezary wyznaczył sobie bowiem inny cel swojej medytacji nad tekstem Objawienia św. Jana. Jako gorliwemu duszpasterzowi zależało mu zapewne także na przedstawieniu biblijnej interpretacji trudnej sytuacji Kościoła katolickiego w Galii w 1. poł. VI wieku. Dlatego w dalszej części swoich wstępnych rozważań napisze:

„cokolwiek w czytaniu Objawienia usłyszycie, czy to o Synu Człowieczym, czy o gwiazdach, aniołach, świecznikach, czterech zwierzętach, orle lecącym pośrodku nieba i resztę, wszystko przyjmujcie jako wydarzenia, które dokonują się w Chrystusie i w Kościele lub też odczytujcie jako przepowiadanie za pomocą figur"24.

To wstępne założenie, iż treści zawarte w Apokalipsie należy odnosić do Chrystusa i do Kościoła, będzie Cezary konsekwentnie realizował we wszystkich następnych częściach swoich rozważań. Komentując wybrane fragmenty Janowego pisma stara się odnaleźć w nich klucz do zrozumienia i wytłumaczenia współczesnych mu wydarzeń. W ten sposób biskup Arles będzie swoją egzegezą dokonywał aktualizacji treści zawartych w Objawieniu św. Jana. Przyjęta przez niego metoda jest charakterystyczna dla okresu patrystycznego. Ojcowie Kościoła powszechnie uważali, że przesłanie zawarte w Piśmie Świętym jest zawsze aktualne ${ }^{25}$. Dla Cezarego było więc oczywiste, że i w Apokalipsie można odnaleźć wskazania dotyczące bieżącej sytuacji Kościoła w Galii i w ówczesnym świecie. Warto przypomnieć, że w czasach pasterzowania Cezarego Galia była miejscem wielu wojen. W chwili objęcia przez Cezarego stolicy biskupiej w $503 \mathrm{r}$. Arles znajdowało się pod panowaniem ariańskich Wizygotów. Następnie, w wyniku kolejnej wojny, przeszło pod panowanie

${ }^{23}$ Caesarius Arelatensis, Expositio in Apocalypsim I, ed. G. Morin, w: S. Caesarii Arelatensis Opera omnia, vol. 2, Maredsous 1942, 210, thum. A. Strzelecka: Cezary z Arles, Wyktad Objawienia świętego Jana, w: Cezary z Arles, Pisma dogmatyczne i egzegetyczne, POK 29, Poznań 2004, 93.

${ }^{24}$ Tamże.

${ }^{25}$ Charakterystyczna dla Ojców Kościoła metoda interpretacji tekstów biblijnych została opisana w dokumencie Papieskiej Komisji Biblijnej z 23 kwietnia 1993 r.: „Skłonność do posługiwania się alegorią ma swoje źródło także w przekonaniu, że Biblia jako księga Boża, została przekazana przez Boga Jego ludowi, to znaczy Kościołowi. Wobec tego nic z tej księgi nie może pozostać niewykorzystane i jakby definitywnie pozbawione znaczenia. Skierowane przez Boga do ludu chrześcijańskiego orędzie powinno być zawsze aktualne" (Papieska Komisja Biblijna, Interpretacja Pisma Świętego w Kościele III 2, Poznań 1994, 84). 
Ostrogotów, którzy również byli wyznawcami arianizmu, by wreszcie w 536 roku znaleźć pod panowaniem wyznających katolicyzm Franków ${ }^{26}$. Ta trudna sytuacja Kościoła w Galii znajduje swój oddźwięk w interpretacji Apokalipsy dokonanej przez biskupa.

Tak więc według autora komentarza w Apokalipsie św. Jana można odnaleźć wiele symboli i figur wyrażających potępienie wszelkich herezji. Przytoczmy kilka przykładów:

„«I rozgniewał się Smok na Niewiastę i odszedł rozpocząć walkę z resztą jej potomstwa» (Ap 12, 17), czyli skoro zobaczył, że nie jest w stanie ciagnąć dalej prześladowań, które zwykł rozpoczynać za pośrednictwem pogan, gdyż przez usta ziemi świętej, to znaczy za przyczyną modlitw świętych są one niweczone, wznieca herezje. «I stanął na piasku morza» (Ap 12, 18), to znaczy nad wielką liczbą heretyków. [...] «Łapy jej - jakby niedźwiedzia», to jej przywódcy, «paszcza jej» - to jej polecenie. «A Smok dał jej swą moc» (Ap $12,18)$. Obecnie widzimy, że heretycy są silni w doczesności, gdyż posiadają moc diabelską, i jak niegdyś poganie, niszczą teraz Kościół”27.

Smok, bestia to diabeł, który prześladuje Kościół. Najpierw czynił to rękami pogan, wzniecając przeciwko chrześcijanom prześladowania, teraz zaś niszczy Kościół rękami heretyków. Siła herezji, której Cezary doświadczał osobiście, jest - według niego - siłą samego diabła. Interpretując wybrane fragmenty Apokalipsy autor komentarza odnosi się do konkretnych praktyk realizowanych przez wspólnoty znajdujące się poza Kościołem katolickim, np. rebaptyzacji:

„«I wielu ludzi pomarło od wód, ponieważ stały się gorzkie» (Ap 8, 11).

Ludzie pomarli z powodu wód. W oczywisty sposób wskazuje tutaj [Jan] na

ludzi, którzy ponownie przyjmują chrzest”28.

Problem powtórnego chrztu pojawia się w Objaśnieniach jeszcze kilka razy. Czyżby praktyka ta była dość częsta w środowisku heterodoksyjnym Galii? Trudno dać jednoznaczną odpowiedź. Innym problemem, który zajmuje biskupa Arles, był temat szerzącego się błędnego poglądu na temat łaski. Komentując fragment Ap 1, 14: „Głowa Jego i włosy jak biała wełna, jak śnieg”, Cezary pisze:

„Białe włosy oznaczają mnóstwo ludzi odzianych w białe szaty, czyli neofitów po chrzcie. Wymienił wełnę, gdyż są oni owcami Chrystusa. Wspomniał

${ }^{26}$ Por. P. Wygralak, Postawa Cezarego z Arles wobec przemian religijnych i politycznych w Galii VI wieku, w: Starożytny chrześcijanin w obliczu przemian dziejowych, red. B. Częsz, Poznań 2011 = TPatr 8 (2011) 143-156; J. Strzelczyk, Goci. Rzeczywistość i legenda, Poznań 2015, 228-248.

${ }^{27}$ Caesarius Arelatensis, Expositio in Apocalypsim X, ed. Morin, II, s. 245, POK 29, 144-145.

${ }^{28}$ Tamże VI, ed. Morin, II, s. 230, POK 29, 122. 
też śnieg, ponieważ jak śnieg sam z siebie pada z nieba, tak również łaska chrztu przychodzi bez względu na poprzednie zasługi [człowieka]"29.

Symbol białych włosów to symbol wody, niezbędnej materii w sakramencie chrztu, natomiast spadający śnieg jest symbolem „spadającej” na człowieka w czasie obrzędu chrztu łaski Bożej ${ }^{30}$. Dla biskupa Arles - podobnie jak wcześniej dla Augustyna - jest oczywiste, że łaska chrztu jest łaską darmo daną ${ }^{31}$. To jednoznaczne sformułowanie z jednej strony wyraża prawowierną naukę Kościoła, z drugiej zaś jest wyraźnym przeciwstawieniem się myśli marsylian, kwestionujących prymat łaski ${ }^{32}$. Problem ten został podjęty w czasie obrad zwołanego przez Cezarego synodu w Orange (529), gdzie przedstawiono prawowierną naukę o pierwszeństwie łaski ${ }^{33}$.

Cezary broniąc prawowierności odnajdzie w Apokalipsie symbole obrazujące karę, która czeka na wszystkich heretyków:

„«Potem ujrzałem: oto biały obłok» - czy też jaśniejący - «a na obłoku siedzącego Syna Człowieczego» (Ap 14, 14), to znaczy Chrystusa. [...] «Miał złoty wieniec na głowie» - złote wieńce mieli wspomniani starcy - «a w ręku swoim ostry sierp» $(A p 14,14)$. Ów ostry sierp oddziela katolików od heretyków, świętych od grzeszników, zgodnie z nauką Pana o żniwiarzach" ${ }^{34}$.

A zatem w dniu sądu Chrystus oddzieli zbawionych od skazanych na potępienie. Wśród tych pierwszych znajdą się katolicy i święci. Natomiast heretycy oraz grzesznicy będą potępieni i za karę wrzuceni do „tłoczni Bożego gniewu” $(\text { Ap } 14,19)^{35}$. W ten sposób biskup Arles wskazuje wyraźnie, że wszystkich, którzy są wierni nauce Kościoła, czeka nagroda wieczna. Natomiast na heretyków, którzy są poza Kościołem, spadnie gniew Boga, a jego wyrazem jest „deptanie w tłoczni”" ${ }^{36}$. Obraz ten, zaczerpnięty przez autora Apokalipsy z Iz 63, 2-4, został zapewne uwypuklony przez Cezarego jako bardzo wyrazisty w swojej formie i czytelny dla obeznanych z produkcją wina mieszkańców Prowansji, którzy dokładnie wiedzieli, co dzieje się w tłoczni z winnymi gronami. Wszyscy heretycy i grzesznicy wraz z diabłem i jego aniołami zostaną

${ }^{29}$ Tamże I, ed. Morin, II, s. 211, POK 29, 95.

${ }^{30}$ Por. R. Kimsza, Cezarego z Arles, rozumienie symboli Apokalipsy św. Jana Apostoła (1-9), „Roczniki Teologii Katolickiej” 11 (2012) fasc. 2, 51.

${ }^{31}$ Por. Augustinus Hipponensis, Contra duas epistolas Pelagianorum IV 12; De gratia Christi et de peccato originali I 34. Zob. C. Baumgartner, Laska Chrystusowa, w: Tajemnica Chrystusa, thum. R.Z. Karska, Studia Instituti Thomistici 3, Poznań - Warszawa - Lublin 1969, 361-362.

${ }^{32}$ Por. Baumgartner, Laska Chrystusowa, s. 368-372.

${ }^{33}$ Por. Concilium Arausicorum (529), can. 1-25, w: Dokumenty synodów od 506 do 553 roku, [wyd. łacińsko-polskie], układ i oprac. A. Baron - H. Pietras, tłum. A. Caba, ŹMT $73=$ SCL 7 , Kraków 2014, 128-135; Definitio fidei, SCL 7, 135-137.

${ }^{34}$ Caesarius Arelatensis, Expositio in Apocalypsim XI, ed. Morin, II, s. 249, POK 29, 150-151.

${ }^{35}$ Por. tamże.

${ }^{36}$ Por. tamże. 
zmiażdżeni w tłoczni. Biskup Arles cytuje tu kolejny wiersz Apokalipsy: „A z tłoczni krew wytrysnęła” (Ap 14, 20) $)^{37}$.

Aby dopełnić w słuchaczach pewności, że jedyna prawda głoszona jest w Kościele katolickim, Cezary stara się wskazać w tekście Apokalipsy te fragmenty, które poświadczają jego Boskie pochodzenie. Należy zwrócić tu uwagę na komentarz do Ap 5, 6: „I ujrzałem między tronem z czworgiem Zwierząt a kręgiem Starców stojącego Baranka, jakby zabitego, a miał siedem rogów i siedmioro oczu, którymi jest siedem Duchów Boga wysłanych na całą ziemię”. Biskup Arles komentując ostatni fragment wiersza stwierdza: „Jasno widać, że nikt poza Kościołem nie może posiadać Ducha Bożego"38. W ten sposób Cezary wpisuje się w szereg starożytnych teologów głoszących prawdę, że tylko w Kościele katolickim obecny jest Duch Święty ${ }^{39}$. Podobną myśl wyrazi biskup Arles w komentarzu do Ap 21, 22: „,bo jego «świątynią jest Pan Bóg wszechmogący» oraz Baranek”, tzn. że „Kościół jest w Bogu i w Kościele jest Bóg (in Deo est ecclesia, et in ecclesia Deus)"40. Ponadto w dalszych fragmentach komentarza Cezary, odnosząc się do figur miasta położonego na górze i oblubienicy Baranka, podkreśla, że to Kościół katolicki jest Oblubienicą Baranka ${ }^{41}$, ,jest bowiem złoty, ponieważ jego wiara błyszczy niczym złoto" ${ }^{42}$, „Kościołem nie kieruje światło czy żywioły świata doczesnego, lecz jest on prowadzony poprzez ciemności tego świata przez Chrystusa - Wieczne Słońce" ${ }^{43}$. Tymi obrazami Kościoła jako Oblubienicy Baranka, mieszkania Boga, biskup Arles chce umocnić wiernych do wytrwania w ortodoksyjnej wierze, którą głosi Kościół katolicki.

W omawianym komentarzu do Apokalipsy odnajdujemy więc wskazany przez Papieską Komisję Biblijna, jako typowy dla egzegezy patrystycznej, jej charakter pastoralny ${ }^{44}$. Cezaremu jako duszpasterzowi zależało na wskazaniu w Apokalipsie treści ważnych dla pogłębienia religijnej wiedzy wiernych, ale również dla rozwoju duchowego słuchaczy. W tym miejscu warto wspomnieć, że biskup Arles zachęcał swoich słuchaczy do intensywnej, systematycznej lektury Pisma Świętego ${ }^{45}$.

${ }^{37}$ Por. tamże. Zob. Wygralak, Święty Cezary z Arles jako egzegeta i teolog, s. 26.

${ }^{38}$ Caesarius Arelatensis, Expositio in Apocalypsim IV, ed. Morin, II, s. 222, POK 29, 110.

${ }^{39}$ Por. S. Manna, La Spirito Santo come dono fatto alla chiesa, „Nicolaus” 8 (1982) fasc. 2, 311 321; B. Częsz, Zwiqzek Ducha Świętego z Kościolem w ujęciu świętego Ireneusza i w interpretacji montanistycznej, Poznań 1991, 81-103.

${ }^{40}$ Caesarius Arelatensis, Expositio in Apocalypsim XIX, ed. Morin, II, s. 274, POK 29, 186.

${ }^{41}$ Por. tamże, ed. Morin, II, s. 273, POK 29, 184: „Chodź, ukażę ci Oblubienicę, Małżonkę Baranka. I uniósł mnie w zachwyceniu na górę wielką i wyniosłą, - górą nazywa Chrystusa - i ukazał mi Miasto Święte, Jeruzalem zstępujące z nieba od Boga. Miastem położonym na górze i Oblubienicą Baranka jest Kościół”.

${ }^{42}$ Tamże, ed. Morin, II, s. 274, POK 29, 185.

${ }^{43}$ Tamże, POK 29, 186.

${ }^{44}$ Por. Papieska Komisja Biblijna, Interpretacja Pisma Świętego w Kościele III 2, s. 84.

${ }^{45}$ Por. P. Wygralak, Formacja biblijna $w$ duszpasterstwie VI wieku na przykładzie działalności 
Na pierwszym miejscu Cezary starał się w swoich słuchaczach wyrobić umiłowanie Kościoła katolickiego. To w tym Kościele chrześcijanin otrzymuje wszelkie dobra niezbędne w życiu duchowym. Tak więc wskazuje, że pierwszym i fundamentalnym dla życia duchowego człowieka dobrem jest chrzest. Temat chrztu można odnaleźć w wielu miejscach omawianego komentarza. Warto zwrócić uwagę na kilka z nich:

„«I dam mu biały kamyk», czyli ciało czyste przez chrzest, «a na kamyku wypisane imię nowe», to znaczy znajomość Syna Człowieczego, «którego [imienia] nikt nie zna oprócz tego, kto [je] otrzymuje» $($ Ap 2, 17)"46

„«To ci, którzy przychodzą z wielkiego ucisku i opłukali swe szaty w krwi Baranka» (Ap 7, 14). Nie są to zaś jedynie męczennicy, jak niektórzy sądza, ale cały lud stanowiący Kościół. Powiedział też, że nie opłukali swoich szat we własnej krwi, ale w krwi Baranka, to znaczy w łasce Bożej przez Jezusa Chrystusa naszego Pana, zgodnie ze słowami Pisma: «i krew Syna Jego oczyściła nas» $(1 \mathrm{~J} 1,7){ }^{\prime 47}$.

„Aby zaś pokazać, że wspomniane tysiąc lat toczy się w obecnym życiu, mówi: «To jest pierwsze zmartwychwstanie» (Ap 20, 5). To bowiem zmartwychwstanie, w którym wstajemy na nowo do życia przez chrzest, o czym Apostoł pisze: «Jeśliście więc razem z Chrystusem powstali z martwych, szukajcie tego, co w górze» $(K o l 3,1)$ oraz: «jako ci, którzy ze śmierci przeszli do życia» $(\mathrm{Rz} 6,13)^{\prime \prime 48}$.

To w tym sakramencie otrzymuje chrześcijanin uwolnienie od grzechu i nowe imię, które jest wyrazem poznania Jezusa Chrystusa. To w tym sakramencie - podkreśla biskup Arles - ,przyoblekamy się w Chrystusa i napełniani jesteśmy radością Ducha Świętego" "49. Nie chodzi więc jedynie o intelektualne poznanie Chrystusa, ale nawiązanie z Nim głębokiej więzi duchowej. Dostrzegamy tu przejawy pogłębionej teologii chrztu świętego: owocem chrztu jest nie tylko odpuszczenie grzechów, ale i przyobleczenie się w Chrystusa oraz napełnienie Duchem Świętym. I przez chrzest dokonuje się pierwsze zmartwychwstanie człowieka, który dotąd pogrążony w śmierci grzechu, dzięki łasce chrztu zmartwychwstaje do nowego życia. Warto zwrócić uwagę na obycie biskupa Arles także z innymi tekstami Pisma Świętego.

W swoim komentarzu do Apokalipsy Cezary zwraca też uwagę na władzę odpuszczania grzechów, którą posiada Kościół. Prawdę tę odnajduje w słowach „mam klucze śmierci i Otchłani” (Ap 1, 18). Jego zdaniem:

św. Cezarego z Arles († 543), w: Ewangelia - Tajemna czy Dobra Nowina, red. T. Siuda, Biblia i Ekumenizm 3, Poznań 2006, 111-124.

${ }^{46}$ Caesarius Arelatensis, Expositio in Apocalypsim II, ed. Morin, II, s. 217, POK 29, 103.

${ }^{47}$ Tamże VI, ed. Morin, II, s. 229, POK 29, 119-120.

${ }^{48}$ Tamże XVIII, ed. Morin, II, s. 272, POK 29, 178-179.

${ }^{49}$ Tamże VI, ed. Morin, II, s. 229, POK 29, 120. 
„kto wierzy i ochrzci się, jest uwolniony od śmierci i Otchłani. Klucze owe posiada też Kościół, bowiem zapowiedział [Pan]: «Którym odpuścicie grzechy, są im odpuszczone, a którym zatrzymacie, są im zatrzymane» (J 20, 23)" ${ }^{\prime 50}$.

Ten fragment Objaśnienia zwiera bardzo szeroki komentarz na temat konieczności czynienia pokuty zarówno przez świeckich, jak i duchownych. Nikt bowiem nie jest bez grzechu, wszyscy więc powinni każdego dnia czynić zadość za swoje przewinienia ${ }^{51}$. Nie brak w tekście komentarza zachęt do praktykowania ascezy. Szczególny akcent położony jest na rozdawanie jałmużny. Dla Cezarego jest oczywiste, że kiedy św. Jan mówi: „Jesteś ani gorący, ani zimny" (Ap 3, 16) to chce powiedzieć, przede wszystkim bogatym chrześcijanom, że ,jesteś bezużyteczny”. Zdaniem egzegety

„można te słowa przyjąć jako odnoszące się wprost do bezużytecznych bogaczy, którzy choć mają możliwość, nie dają jałmużny. Nie są ubodzy, ponieważ posiadają środki materialne. Nie sąjednak bogaci, gdyż nie wykorzystują swojego bogactwa"52.

Warto zauważyć, że w swoim komentarzu biskup wskazuje na inne od powszechnego użycia rozumienie terminów „,bogaty” i „ubogi” . Bogactwo nie polega jedynie na posiadaniu dóbr materialnych, ale na właściwym ich wykorzystaniu, co należy rozumieć jako hojność w dzieleniu się z potrzebującymi. Bogaty materialnie jest jednak ,ubogi”, jeśli nie potrafi podzielić się swoimi dobrami z cierpiącymi prawdziwe ubóstwo współbraćmi. Jaka powinna więc być postawa chrześcijanina, wskazuje - zdaniem kaznodziei - kolejny wiersz Apokalipsy: „Radzę ci nabyć złota” (Ap 3, 18). Nabywanie tego złota należy rozumieć jako dawanie biednym jałmużny i wypełnienie życia dobrymi uczynkami $^{53}$. Taki człowiek staje się prawdziwie bogaty.

Objaśnienie Objawienia św. Jana w założeniu św. Cezarego nie miało być klasycznym komentarzem egzegetycznym do ostatniej księgi Nowego Testamentu. Przyjęta przez autora komentarza forma homilii zakładała już pastoralny charakter całego przedsięwzięcia. Posługując się metodą alegoryczna, biskup Arles starał się odnaleźć i odczytać w przesłaniu Apokalipsy treści, które mogłyby posłużyć do interpretacji sytuacji Kościoła w Galii w VI wieku. Jest więc to dzieło przede wszystkim świadectwem próby interpretacji Apokalipsy przez duszpasterza i teologa zderzającego się w swojej posłudze z konkretnymi problemami duszpasterskimi i teologicznymi. Dla biskupa Arles, wielkiego zwolennika udostępnienia tekstów biblijnych wiernym, ważne

\footnotetext{
${ }^{50}$ Tamże II, ed. Morin, II, s. 215, POK 29, 100.

${ }^{51}$ Por. tamże.

${ }^{52}$ Tamże III, ed. Morin, II, s. 218-219, POK 29, 105.

${ }^{53}$ Por. tamże.
} 
było, aby wskazywać na aktualność przesłania zapisanego w księgach Pisma Świętego. Posiadamy bardzo mało informacji na temat omawianego dzieła. Mając na uwadze pierwsze kazanie Cezarego z jego obszernego zbioru kazań, które skierował do kapłanów i biskupów, możemy przyjąć hipotezę, że i tymi szkicami chciał ich biskup wesprzeć zarówno na polu troski o zachowanie prawowierności, jak i na polu objaśniania trudnej do interpretacji ostatniej księgi Nowego Testamentu. Pamiętając, że Objaśnienie nie jest w pełni dziełem oryginalnym - autor korzystał z komentarza Tykoniusza - można jednak pogratulować Cezaremu odwagi, że podjął się dokonania egzegezy Apokalipsy, księgi tak bogatej w symbolikę. Po raz kolejny można więc uznać biskupa Arles nie tylko za wspaniałego duszpasterza, świetnego organizatora życia kościelnego, obrońcę prawowierności, sprawnego teologa, ale również dobrego egzegetę, co potwierdzają też jego kazania, w których komentuje teksty Starego i Nowego Testamentu.

\section{THE PASTORAL MESSAGE OF THE COMMENTARY OF ST. CAESARIUS OF ARLES ON THE APOCALYPSE OF ST. JOHN}

\section{(Summary)}

The article discusses the commentary of St. Caesarius of Arles on the Apocalypse of St. John. The bishop of Arles wrote his commentary on the basis of the Ticonius's study. Due to this fact, the work of Caesarius, which has been saved all in one piece, is an extremely important source of information about the commentary of Ticonius and may be very useful in the process of its reconstruction. The explication of the Apocalypse, written by the Gallic shepherd, is practical. The author tried to make comments on the Apocalypse in the context of the situation of the Church in Gaul. He was more interested in ecclesiological message of St. John's text rather than in its eschatological message. In consequence, the commentary was very practical and might have been used by priests who had to face such problems as the schism of the Church, rebaptism and relations with heretics.

Key words: Caesarius of Arles, Ticonius, The Apocalypse of St. John, ecclesiology, orthodoxy, heterodoxy.

Słowa kluczowe: Cezary z Arles, Tykoniusz, Apokalipsa św. Jana, eklezjologia, ortodoksja, heterodoksja.

\section{BIBLIOGRAFIA}

\section{Źródła}

Ambrosius Autpertus, Expositionis in Apocalypsin, ed. R. Weber, CCCM 27-27A, Turnhout 1975.

Andreas Caesariensis, Commentarii in Apocalypsin, PG 106, 215-458, 1387-1394. 
Apokalipsa świętego Jana, Wstęp, przekład, komentarz A. Jankowski, Poznań 1959.

Apringius Pacensis, Tractatus in Apocalypsin, ed. R. Gryson, CCL 107, Turnhout 2003, $35-97$.

Beatus Liebanensis, Tractatus de Apocalipsin, ed. R. Gryson - M.-C. de Bièvre, CCL 107B-C, Turnhout 2012.

Beda Venerabilis, Explanatio Apocalypsis, PL 93, 129-206.

Caesarius Arelatensis, Expositio in Apocalypsim, ed. G. Morin, w: S. Caesarii Arelatensis Opera omnia, vol. 2, Maredsous 1942, 210-277, tłum. A. Strzelecka: Cezary z Arles, Wykład Objawienia świętego Jana, w: Cezary z Arles, Pisma dogmatyczne i egzegetyczne, POK 29, Poznań 2004, 93-191.

Concilium Arausicorum (529), Canones, w: Dokumenty synodów od 506 do 553 roku, [wyd. łacińsko-polskie], układ i oprac. A. Baron - H. Pietras, tłum. A. Caba, ŹMT 73 = SCL 7, Kraków 2014, 128-135.

Concilium Arausicorum (529), Definitio fidei, w: Dokumenty synodów od 506 do 553 roku, [wyd. łacińsko -polskie], układ i oprac. A. Baron - H. Pietras, tłum. A. Caba, ŹMT 73 = SCL 7, Kraków 2014, 135-137.

Eusebius Caesariensis, Historia ecclesiastica, ed. G. Bardy, SCh 31, 41, 55, 73, Paris 1952-1960.

Hieronymus, De viris illustribus, PL 23, 601-720.

Primasius Hadrumetinus, Commentarius in Apocalypsin, ed. A.W. Adams, CCL 92, Turnholti 1985.

Tyconius, Expositio Apocalypseos, ed. R. Gryson, CCL 107A, Turnhout 2011.

Victorinus Poetovionensis, Commentarii in Apocalypsim Joannis, ed. M. Dulaey, SCh 423, Paris 1997.

\section{Opracowania}

ADAmiak S., Eklezjologiczny charakter Komentarza do Apokalipsy donatysty Tykoniusza, BPTh 5 (2012) 151-162.

Apocalisse di Giovanni, con commento tratto dai Padri, Santi e Mistici della Chiesa, Montespertoli 1997.

The Apocalypse in the Middle Ages, ed. R.K. Emmerson - B. McGinn, New York 1993.

Baumgartner C., Łaska Chrystusowa, w: Tajemnica Chrystusa, tłum. R.Z. Karska, Studia Instituti Thomistici 3, Poznań - Warszawa - Lublin 1969, 311-566.

Correau J., L'exégèse allégorique de saint Césaire d'Arles, BLE 78 (1977) 181-206.

CzĘS B., Zwiazek Ducha Swiętego z Kościołem w ujęciu świętego Ireneusza i w interpretacji montanistycznej, Poznań 1991.

Diobounitis C. - Harnack A. von, Der Scholien Kommentar des Origenes zur Apokalypse Johannis, TU 38, 3, Leipzig 1911.

DybCZyŃSKA J., Egzegeza alegoryczna w kazaniach Cezarego z Arles jako narzędzie głoszenia stowa Bożego, w: Refleksja Ojców Kościoła nad słowem Bożym, red. B. Częsz, Poznań 2009 = TPatr 6 (2009) 121-142.

GGrYsOn R., Fragments inedits du commentaire de Tyconius sur l'Apocalypse, RBen 107 (1997) 189-226.

Kelly J.F.T., Early Medieval Evidence for Twelve Homilies by Origen on the Apocalypse, VigCh 39 (1985) 273-266.

Kimsza R., Cezarego z Arles, rozumienie symboli Apokalipsy św. Jana Apostoła (1-9), „Roczniki Teologii Katolickiej” 11 (2012) fasc. 2, 47-59. 
Langärtner G., Der Apokalypse-Kommentar des Caesarius von Arles, ThG 57 (1967) 210-225.

Lo Bue F. - Wilis G.G., The Turin Fragments of Tyconius' Commentary on Revelation, Text and Studies. New Series 7, Cambridge 1963.

Manna S., La Spirito Santo come dono fatto alla chiesa, „Nicolaus” 8 (1982) fasc. 2, 311-321.

Morin G., Le commentaire homilétique de S. Cesaire sur l'Apocalypse, RBen 45 (1933) 43-61.

Naumowicz J., Wstęp, w: Pierwsze tacińskie komentarze do Apokalipsy, Warszawa 2011, 12-30.

Pose E.R., Introducción, w: Cesáro de Arlés, Comentario al Apocalipsis, Madrid 1994, 7-19.

Strzelczyk J., Goci. Rzeczywistość i legenda, Poznań 2015.

WygralaK P., Formacja biblijna $w$ duszpasterstwie VI wieku na przykładzie działalności św. Cezarego z Arles († 543), w: Ewangelia - Tajemna czy Dobra Nowina, red. T. Siuda, Biblia i Ekumenizm 3, Poznań 2006, 111-124.

Wygralak P., Postawa Cezarego z Arles wobec przemian religijnych $i$ politycznych w Galii VI wieku, w: Starożytny chrześcijanin w obliczu przemian dziejowych, red. B. Częsz, Poznań 2011 = TPatr 8 (2011) 143-156.

Wygralak P., Święty Cezary z Arles jako egzegeta i teolog, w: Cezary z Arles, Pisma dogmatyczne i egzegetyczne, POK 29, Poznań 2004, 7-28.

Żurek A., Wstęp, w: Cezary z Arles, Homilie do Księgi Rodzaju, Objaśnienie Apokalipsy św. Jana, BOK 17, Kraków 2002, 5-20. 